\title{
Influence of Farmer Capacity Building in Institutional Linkages on Performance of Smallholder Irrigation Projects in Migori County, Kenya
}

\author{
Asawo Leopold Othieno, Anne Aseey, Chandi John Rugendo \\ ODeL Campus, University of Nairobi, Nairobi, Kenya \\ Email: asawoleo@gmail.com
}

How to cite this paper: Othieno, A.L. Aseey, A. and Rugendo, C.J. (2021) Influence of Farmer Capacity Building in Institutional Linkages on Performance of Smallholder Irrigation Projects in Migori County, Kenya. Agricultural Sciences, 12, 726-737. https://doi.org/10.4236/as.2021.127047

Received: June 15, 2021

Accepted: July 12, 2021

Published: July 15, 2021

Copyright $(\odot 2021$ by author(s) and Scientific Research Publishing Inc. This work is licensed under the Creative Commons Attribution International License (CC BY 4.0).

http://creativecommons.org/licenses/by/4.0/

\begin{abstract}
The smallholder irrigation sector in Kenya is considered inadequately developed. The study views unawareness of critical success factors in the smallholder irrigation sector as contributing to poor performance of smallholder irrigation projects. Consequently, the study investigated influence of farmer capacity building in institutional linkages on performance of smallholder irrigation projects in Migori County, Kenya. The study embraced a pragmatic view of philosophy, and used cross sectional and correlation research design. The target population was 2815, and comprised farmers drawn from fifteen smallholder irrigation projects that receive water from River Kuja through Lower Kuja Project. The sample size was 341 . The study used systematic random sampling procedure to draw the sample, and collected data using questionnaire. Data was analysed using descriptive and inferential statistics. The study established that farmer capacity building in institutional linkages has a significant influence on performance of smallholder irrigation projects $(\mathrm{r}=$ $0.803, \mathrm{R}^{2}=0.645, \mathrm{~F}(5,331)=120.254$ and $\left.\mathrm{p}<0.000<0.05\right)$. Thus, the study recommends that Migori County Government come up with policies that link smallholder irrigation projects in Lower Kuja Project to institutions that provide land ploughing services, certified seeds and fertilisers, control of crop pests and diseases, transportation of farm produce and marketing of farm produce.
\end{abstract}

\section{Keywords}

Institutional Linkages, Critical Success Factors, Irrigation Management Transfer, Smallholder Irrigation Projects 


\section{Introduction}

Expansion in area under irrigation has increased conflicts among irrigating communities over water use rights. According to [1], over the last decade, countries with substantial irrigation, including Mexico, Chile, India, Philippines and Columbia have embraced irrigation management transfer (IMT). Likewise, Sub-Saharan Africa (SSA) countries are increasingly adopting policies in smallholder irrigation that support IMT [2]. However, despite its benefits, IMT has thrust farmers in the forefront of conflict resolution [3], and necessitated capacity building [4]. According to [5], critical success factors (CSFs) are more useful in decision-making than planning, implementation, cost and time overruns and quality control, traditional concerns in project management. CSFs include project type, project team, organisation and external environment [6]. Different studies identify different CSFs in project management and there is disagreement on CSFs that affect project success, and the assumption that project management ends with deliver of projects has led to failure to consider critical criteria affecting projects after delivery [7].

The Government of Kenya has adopted irrigation management transfer in smallholder irrigation development. Kenya has used tenant farmer, service provision and IMT as models in irrigation management, but only IMT model has had notable success [3]. IMT provides an avenue for resolving conflict between irrigating communities in smallholder irrigation projects [8] [9]. According to [10], smallholder irrigation sector in Kenya comprise projects such as Yatta Furrow and Njoro Kubwa, which are managed by water undertakers, and projects such as Kibirigwi and Mitunguu, which are managed by Irrigation Water User Associations (IWUAs). The Irrigation Act (1966) mandated the National Irrigation Authority (NIA) to oversee large-scale irrigation in Kenya, and the Ministry of Agriculture (MOA) to oversee smallholder irrigation development [11].

Project success entails use of project-specific approaches to development. However, weak institutional capacity, lack of credit and poor market access has contributed to poor performance in smallholder irrigation projects [12]. Likewise, poor institutional capacity has led to organisational weaknesses in smallholder irrigation projects [13]. Consequently, while capacity building enables farmers to exploit opportunities in smallholder irrigation [14], proper identification of CSFs can improve success of smallholder irrigation projects in planning, resource mobilisation, implementation and control. Thus, the study examined influence of farmer capacity building in institutional linkages on performance of smallholder irrigation projects in Migori County, Kenya.

\section{Statement of the Problem}

Despite the potential to contribute to food security and poverty alleviation, exploitation of irrigation in Kenya has not translated into project success. For instance, studies identify irrigation potential in Migori County as being in excess 
of 16,500 hectares arising from Rivers Kuja and Migori [15]. However, [16] describes food poverty in Migori County as $32 \%$, twice that in Nyeri and Meru Counties ( $15.5 \%$ each). Poverty incidence in Migori County is $41.2 \%$, compared to the national figure of $36.1 \%$ [16]. This means that Migori County has not adequately exploited its irrigation potential. While there is significant research in smallholder irrigation addressing the relationship between farmer participation and project sustainability [17] [18] [19], and between farmer participation and project performance [20] [21] [22] [23], there is limited research addressing the relationship between capacity building in institutional linkages and performance of smallholder irrigation projects. According to [5], whereas project management practitioners consider planning, project implementation, cost and time overruns and quality non-achievement as main concerns in project management, CSFs are important inputs into project management and can lead to project success, either directly or indirectly. Therefore, the study has identified a gap in knowledge between farmer capacity building in institutional linkages and performance of smallholder irrigation projects in Migori County, Kenya.

\section{Objectives of the Study}

The objective of the study was to evaluate influence of farmer capacity building in institutional linkages on performance of smallholder irrigation projects in Migori County, Kenya.

\section{Literature Review}

Institutional linkages assist farmers overcome challenges to commercialisation of agriculture. Poor farm practices, poor quality control, poor roads network, and sale of farm produce in raw form contributes to loss of revenue to smallholder farmers [17]. Smallholder irrigation farmers in SSA face challenges related to poor market information, poor roads network, poor quality control, and misperception on opportunities by policy makers [18] [24]. Kenya exports only $16 \%$ of its agricultural produce in processed form, leading to loss of profits to farmers and lose of opportunities in agro-processing industry [25]. Whereas export quality assurance is a problem to smallholder farmers, and sale of farm produce in local markets represents losses in opportunities [26], attempts to assist farmers to access markets in Europe (EU) have been constrained by failure by farmers to meet EU quality control standards [24]. Farmers in rural areas consume 50\% of their produce, while farmers in peri-urban areas consume $45 \%$, and marketing strategies can enable rural area farmers to acquire better prices for their produce [27]. There is need to train smallholder farmers on quality control for international agricultural markets [28]. Thus, the study examined how farmer capacity building in institutional linkages influence performance of smallholder irrigation projects. Institutional linkages refer to land ploughing services, supply of certified seeds and fertilisers, control of crop pests and disease, transportation of farm produce, and marketing of farm produce. 


\section{Theoretical Framework}

Everett Rogers conceptualised diffusion of innovation theory in 1962 to describe adoption of inventions, so that a decision to use improved ideas is "adoption" [29]. Rogers described diffusion as encompassing knowledge, persuasion, decision (to accept or reject), implementation and confirmation [30]. Adoption follows a normal distribution curve characteristic [29] and depends on relative advantages of innovation, compatibility with recipient's values and needs, ease of use, and triability and observability of innovation [31]. The study suggests that diffusion of innovation explains benefits accrued from institutional linkages. Thus, the study used diffusion of innovation theory to explain farmer capacity building in institutional linkages.

\section{Materials and Methods}

\subsection{Research Philosophy and Design}

The study adopted pragmatism as its philosophy, and used cross sectional and correlation research design. By adopting pragmatism, the researcher integrated both deductive and inductive research approaches, and benefitted from use of objective and subjective research methods. Likewise, the study adopted crosssectional and correlational research design. Cross-sectional survey design is cheaper, compared to longitudinal design, and more appropriate for researchers working under budgetary constraints [32]. Correlational design is useful when investigating if two variables co-vary, to quantify strength of relationship between variables, and to determine causal relationship between variables when it is impractical or unethical to manipulate any of the variables [33].

\subsection{Target Population}

The target population comprised farmers undertaking irrigation in the fifteen smallholder irrigation projects in Migori County that are members of Lower Kuja Irrigation Water Project (LOKIWAP). The researcher selected the fifteen smallholder irrigation projects because NIA has constructed a project to provide water from River Kuja to the fifteen smallholder irrigation projects in Migori County, and the fifteen irrigation projects have benefitted from the project. The target population is 2815 subjects, and comprised farmers who are registered members of the fifteen irrigation projects in Migori County that receive water for irrigation from River Kuja as part of the Lower Kuja Project.

\subsection{Sample Size and Sampling Procedure}

The researcher used tables given by [34] to determine the sample size. According to [34], sample size for a population of 2800 is 338, while that for a population of 3000 is 341 . The target population is 2815, which falls in between 2800 and 3000 . Thus, the study adopted 341 as its sample size. The study used purposive and systematic random sampling techniques to select respondents. 


\subsection{Data Collection Instruments}

The researcher used the questionnaire to collect information. The questionnaire underwent pilot testing prior to use. Piloting was important in ensuring that respondents perceived the questions as intended by the researcher [35]. Use of 30 cases in a pilot study is recommended [36]. Thus, piloting enabled the researcher to familiarise with clarity of the instructions and proper wording of questions, estimation of time required to collect data, use of the data instrument to collect information, and coding and analysis of data.

\subsection{Data Collection Procedures}

Before collecting data, the researcher sought permission from School of Post Graduate Studies (University of Nairobi) and National Council for Science, Technology and Innovation (NACOSTI). After securing the research permit, the researcher held introductory meetings with NIA, Migori County Officials and farmers' leaders. Thereafter, the researcher recruited five research assistants from the study area to administer the questionnaire. Data collection took five days, comprising one day for mobilisation and training of research assistants, three days for administering of the questionnaire, and one day for debriefing after data collection.

\subsection{Data Analysis Techniques}

The study used descriptive and inferential statistics to analyse data. Descriptive statistics included percentages, central tendency (mean) and variability (standard deviation), while inferential statistics included Pearson's correlation analysis. The regression model took the form: $Y=a+b_{1} X_{1}+b_{2} X_{2}+, \cdots,+b_{k} X_{k}+\varepsilon$, where $Y=$ dependent variable, $a=Y$ intercept, $b_{1}, \cdots, b_{k}=$ regression coefficients, and $X_{1}, \cdots, X_{k}=$ measurable indicator, and $\varepsilon=$ error term. Pearson product moment correlation $(\mathrm{r})$ and stepwise regression $\left(\mathrm{r}^{2}\right)$ was analysed based on p-value at $5 \%$ significance level. The study tested the following hypothesis; H1: Farmer capacity building in institutional linkages has a significant influence on performance of smallholder irrigation projects.

$$
Y=a+b_{1} X_{1}+b_{2} X_{2}+b_{3} X_{3}+b_{4} X_{4}+b_{5} X_{5}+\varepsilon .
$$

In Equation (1), $Y=$ performance of smallholder irrigation projects; $a=Y$ intercept, and $b_{1}, b_{2}, b_{3}, b_{4}, b_{5}=$ regression coefficients; $X_{1}=$ land ploughing services, $X_{2}=$ supply of certified seeds and fertilisers, $X_{3}=$ control of crop pests and diseases, $X_{4}=$ transportation of farm produce, $X_{5}=$ marketing of farm produce; $\varepsilon=$ error term.

\section{Findings and Discussion}

\subsection{Descriptive Statistics}

This section deals with influence of farmer capacity building in institutional linkages on performance of smallholder irrigation projects in Migori County. The 
indicators for farmer capacity building in institutional linkages were land-ploughing services, supply of certified seeds and fertilisers, control of crop pests and disease, transportation of farm produce and marketing of farm produce. The study asked participants to indicate their level of agreement with various statements on institutional linkages. Tables 1-5 present views of the farmers.

Table 1. Agreement with statements on land ploughing services.

\begin{tabular}{lcc}
\hline & Mean & Std. Dev. \\
\hline Land ploughing services are available in the project area. & 3.490 & 1.126 \\
I use private land ploughing services to plough land. & 3.638 & 1.147 \\
The project arranges for ploughing of farmers' lands. & 2.232 & 2.836 \\
I use the project ploughing arrangements to plough land. & 2.030 & 0.790 \\
I use my own family labour or oxen to plough land. & 3.134 & 1.383 \\
\hline
\end{tabular}

Table 2. Agreement with statements on supply of certified seeds and fertilisers.

\begin{tabular}{lcc}
\hline & Mean & Std. Dev. \\
\hline Stockists of certified seeds \& fertilisers are available in the project area & 3.232 & 1.227 \\
I buy seeds \& fertilisers from local farm input stockists. & 3.418 & 1.142 \\
The project arranges for supply of seeds \& fertilisers to farmers. & 1.953 & 0.620 \\
I get certified seeds \& fertilisers from the project arrangements. & 1.896 & 0.565 \\
I select my own seeds for planting and use farmyard manure. & 3.074 & 1.340 \\
\hline
\end{tabular}

Table 3. Agreement with statements on control of crop pests and diseases.

\begin{tabular}{lcc}
\hline & Mean & Std. Dev. \\
\hline Crop pests \& disease control services are available in the project area. & 2.967 & 1.140 \\
I use private services to control crop pests \& diseases. & 3.804 & 1.016 \\
The project arranges for crop pests \& disease control for farmers. & 2.036 & 2.731 \\
I use the project arrangements to control crop pests \& diseases. & 1.834 & 0.471 \\
I use traditional methods such as ash to control crop pests \& diseases. & 2.816 & 1.321 \\
\hline
\end{tabular}

Table 4. Agreement with statements on transportation of farm produce.

\begin{tabular}{lcc}
\hline & Mean & Std. Dev. \\
\hline Transport services for farm produce is available in the project area. & 3.323 & 1.170 \\
I use private transport services to transport farm produce. & 3.798 & 1.033 \\
The project arranges for transport of farm produce for farmers. & 1.956 & 0.608 \\
I use the project arrangements to transport farm produce. & 1.896 & 0.538 \\
I use my own means to transport farm produce. & 3.071 & 1.395 \\
\hline
\end{tabular}


Table 5. Agreement with statements on marketing of farm produce.

\begin{tabular}{lcc}
\hline & Mean & Std. Dev. \\
\hline Markets for farm produce are available in the project area. & 3.350 & 1.204 \\
I market farm produce on my own. & 3.807 & 1.027 \\
The project arranges for marketing of farm produce for farmers. & 1.935 & 0.558 \\
I use the project arrangements to market farm produce. & 1.923 & 0.546 \\
I do not look for markets for farm produce. I sell farm produce at farm gate. & 2.039 & 0.930 \\
\hline
\end{tabular}

From the findings in Table 1, respondents agreed that they use private land ploughing services to plough land as shown by a mean of 3.638 and that land ploughing services are available in the project area as shown by a mean of 3.490 . However, respondents were neutral that they use their own family labour or oxen to plough land as shown by a mean of 3.134, but disagreed that the project arranges for ploughing of farmers' lands as shown by a mean of 2.232 and that they use project ploughing arrangements to plough land as shown by a mean of 2.030 .

As per the findings, Table 2 shows that respondents were neutral that they buy seeds and fertilisers from local farm input stockists as shown by a mean of 3.418 and that stockist of certified seeds and fertilisers are available in the project area as shown by a mean of 3.232. Further respondents were neutral that they select their own seeds for planting and use farmyard manure as shown by a mean of 3.074. However, respondents disagreed that the project arranges for supply of seeds and fertilisers to farmers as shown by a mean of 1.953 and that they get certified seeds and fertilisers from project arrangements as shown by a mean of 1.896.

As per Table 3, respondents agreed that they use private services to control crop pests \& diseases as shown by a mean of 3.804. However, respondents were neutral that crop pests \& disease control services are available in the project area as shown by a mean of 2.967 and that they use traditional methods such as ash to control crop pests \& diseases as shown by a mean of 2.816 . The respondents disagreed that the project arranges for crop pests \& disease control for farmers as shown by a mean of 2.036 and that they use the project arrangements to control crop pests \& diseases as shown by a mean of 1.834 .

From Table 4, respondents agreed that they use private transport services to transport farm produce as illustrated by a mean of 3.798. In addition, respondents were neutral that transport services for farm produce is available in the project area as illustrated by a mean of 3.323 and that they use their own means to transport farm produce as illustrated by a mean of 3.071. However, respondents disagreed that the project arranges for transport of farm produce for farmers as illustrated by a mean of 1.956 and that they use the project arrangements to transport farm produce as illustrated by a mean of 1.896 .

As per Table 5, respondents agreed that they market produce on their own as shown by a mean of 3.807 . The respondents were also neutral that markets for 
farm produce are available in the project area as shown by a mean of 3.350 . However, respondents disagreed that they do not look for markets for farm produce as they sell farm produce at farm gate as shown by a mean of 2.039 , and that the project arranges for marketing of farm produce for farmers as shown by a mean of 1.935. Further, respondents disagreed that they use the project arrangements to market farm produce as shown by a mean of 1.923 .

\subsection{Inferential Statistics}

The study used regression analysis to test the hypothesis: "H1: Farmer capacity building in institutional linkages has a significant influence on performance of smallholder irrigation projects". Tables 6-8 present data analyses and results of regression analysis for influence of farmer capacity building in institutional linkages and performance of smallholder irrigation projects.

Table 6. Model summary.

\begin{tabular}{ccccc}
\hline Model & R. & $\mathrm{R}^{2}$ & Adjusted $\mathrm{R}^{2}$ & Std. Error \\
\hline 1 & $0.803 \mathrm{a}$ & 0.645 & 0.640 & 0.310 \\
\hline
\end{tabular}

a. Predictors: (Constant), land ploughing services, supply of certified seeds and fertilisers, control of crop pests and diseases, transportation of farm produce, marketing of farm produce.

Table 7. Analysis of variance (ANOVA).

\begin{tabular}{ccccccc}
\hline \multicolumn{2}{c}{ Model } & Sum of Squares & df & Mean Square & F & Sig. \\
\hline 1 & Regression & 58.327 & 5 & 11.665 & 120.254 & $0.000 \mathrm{~b}$ \\
& Residual & 32.109 & 331 & 0.097 & & \\
Total & 90.436 & 336 & & &
\end{tabular}

a. Dependent variable: Performance of smallholder irrigation projects. b. Predictors: (Constant), land ploughing services, supply of certified seeds and fertilisers, control of crop pests and diseases, transportation of farm produce, marketing of farm produce.

Table 8. Regression coefficients.

\begin{tabular}{lccccc}
\hline \multirow{2}{*}{ Model } & \multicolumn{2}{c}{$\begin{array}{c}\text { Unstandardized } \\
\text { Coefficients }\end{array}$} & $\begin{array}{c}\text { Standardised } \\
\text { Coefficients }\end{array}$ & T & Sig. \\
\cline { 2 - 4 } & Beta & Std. Error & Beta & & \\
\hline (Constant) & 0.981 & 0.121 & & 8.107 & 0.000 \\
land ploughing services & 0.762 & 0.142 & 0.833 & 5.366 & 0.000 \\
supply of certified seeds and fertilisers & 0.652 & 0.124 & 0.718 & 5.258 & 0.000 \\
control of crop pests and diseases & 0.511 & 0.172 & 0.606 & 2.971 & 0.000 \\
transportation of farm produce & 0.617 & 0.109 & 0.789 & 5.661 & 0.000 \\
marketing of farm produce & 0.761 & 0.137 & 0.818 & 5.555 & 0.000 \\
\hline
\end{tabular}

a. Dependent variable: performance of smallholder irrigation projects.

The findings show that $\mathrm{r}=0.803$, indicating that farmer capacity building in institutional linkages strongly influences performance of smallholder irrigation 
projects in Migori County. Similarly, $\mathrm{R}^{2}=0.645$, indicating that farmer capacity building in institutional linkages (land ploughing services, supply of certified seeds and fertilisers, control of crop pests and disease, transportation of farm produce and marketing of farm produce) explains $64.5 \%$ of variations in performance of smallholder irrigation projects in Migori County.

From the ANOVA table, p-value was 0.000 and F-calculated was 120.254. Since p-value was less than 0.05 and F-calculated was greater than F-critical (2.2413), the regression model was significant in explaining influence of land ploughing services, supply of certified seeds and fertilisers, control of crop pests and disease, transportation of farm produce and marketing of farm produce on performance of smallholder irrigation projects in Migori County.

From the results on test of significance, land ploughing services $(\beta=0.762$, $\mathrm{p}=0.000)$, supply of certified seeds and fertilisers $(\beta=0.652, \mathrm{p}=0.000)$, control of crop pests and disease $(\beta=0.511, \mathrm{p}=0.000)$, transportation of farm produce $(\beta=0.617, \mathrm{p}=0.000)$ and marketing of farm produce $(\beta=0.761, \mathrm{p}=0.000)$ are significant at $\mathrm{p}<0.05$ and $95 \%$ confidence level. This implies that farmer capacity building in institutional linkages (land ploughing services, supply of certified seeds and fertilisers, control of crop pests and disease, transportation of farm produce and marketing of farm produce) has a significant influence on performance of smallholder irrigation projects in Migori County. Thus, the alternate hypothesis was accepted and the study concluded that farmer capacity building in institutional linkages has a significant influence on performance of smallholder irrigation projects in Migori County. Smallholder irrigation farmers in SSA face challenges related to poor market information, poor roads network, lack of quality control, and misperception by policy makers on crop opportunities [17]. Attempts to assist smallholder farmers to sale produce in Europe (EU) markets have yielded little success due to failure by farmers to meet EU quality control standards [24]. Thus, [28] advise on training of smallholder farmers on quality control requirements for international agricultural markets.

\section{Conclusions and Policy Recommendations}

The study concluded that farmer capacity building in institutional linkages has a significant influence on performance of smallholder irrigation projects in Migori County. Thus, access to land ploughing services, supply of certified seeds and fertilisers, control of crop pests and disease, transportation of farm produce and marketing of farm produce has substantial influence on project performance. In addition, the study established that Lower Kuja Project does not have a programme for linkages between the smallholder irrigation projects and service providers in agricultural production and marketing. This means that farmers in the smallholder irrigation projects in Lower Kuja Project make their own arrangements for ploughing services, supply of certified seeds and fertilisers, control of crop pests and disease, transportation of farm produce and marketing of farm produce. 
Following the conclusions, the study recommends that Migori County Government should implement a programme to link smallholder irrigation projects in Migori County with institutions that provide land ploughing services, supply of certified seeds and fertilisers, control of crop pests and disease, transportation of farm produce and marketing of farm produce. The study also recommends that policy makers in the Ministry of Agriculture should formulate policies to assist smallholder irrigation projects to commercialise crop production and produce marketing.

\section{Conflicts of Interest}

The authors declare no conflicts of interest regarding publication of this paper.

\section{References}

[1] Van Vuren, G.H., Papin, C. and El-Haouari, N. (2005) Participatory Irrigation Management: Comparing Theory with Practice. A Case Study of the Beni Amir Irrigation Scheme in Morocco. In: Hammani, A., Kuper, M. and Debbarh, A., Eds., La modernisation de L'Agriculture irriguée, Tome 2, Institut Agronomique et Vétérinaire Hassan II, Rabat, Morroco, 174-183. http://hal.cirad.fr/cirad-00188971/

[2] Bjornlund, H., Rooyen, A. and Stirzaker, R. (2017) Profitability and Productivity Barriers and Opportunities in Small-Scale Irrigation Schemes. International Journal of Water Resources Development, 33, 690-704. https://doi.org/10.1080/07900627.2016.1263552

[3] Kahuro, G.W. (2012) Factors Influencing Farmers' Participation in Operation and Maintenance of Smallholder Irrigation Projects in Gichugu Division, Kirinyaga East District, Kenya. Master's Thesis. University of Nairobi, Nairobi.

[4] Svubure, O., Ahlers, R. and van der Zaag, P. (2007) Local Level Participation in Smallholder Formal and Informal Irrigation and the Water Sector Reforms in Zimbabwe: Chinhoyi, Zimbabwe. Chinhoyi University of Technology e-Needs. Proceedings of the International Conference, Valenzano, 14-17 February 2007, 2843-2855.

[5] Alias, Z., Zawawi, E.M.A., Yusof, K. and Aris, N.M. (2014) Determining Critical Success Factors of Project Management Practice: A Conceptual Framework. Procedia-Social and Behavioral Sciences, 153, 61-69. https://doi.org/10.1016/j.sbspro.2014.10.041

[6] Golini, R., Corti, B. and Landoni, P. (2017) More Efficient Project Execution and Evaluation with Logical Framework and Project Cycle Management: Evidence from International Development Projects. Impact Assessment and Project Appraisal, 35, 128-138. https://doi.org/10.1080/14615517.2016.1239495

[7] Frefer, A.A., Mahmoud, M., Haleema, H. and Almamlook, R. (2018) Overview Success Criteria and Critical Success Factors in Project Management. Industrial Engineering \& Management, 7, 1-6. https://doi.org/10.1080/14615517.2016.1239495

[8] Kabutha, C. and Mutero, C.M. (2002) From Government to Farmers Managed Smallholder Rice Schemes: The Case of the Mwea Rice Irrigation Scheme. International Water Management Institute, Colombo, 191-210.

[9] Sarvestani, M., Baghaei, H., Kardani, M. and Bagheri, H. (2011) The Necessity of Transferring Management to Water Users Association in Water Resources Development Projects with Public Participation Approach. 21st International Congress on Irrigation and Drainage, Tehran, 15-23 October 2011, 15-23. 
[10] Ngigi, S.N. (2002) Review of Irrigation Development in Kenya. International Water Management Institute, Colombo, 35-54. https://publications.iwmi.org/pdf/H030832.pdf

[11] Neubert, S., Hesse, V., Iltgen, S., Onyando, J.O., Onchoke, W., Peters, V., Seelaff, A. and Taras, D. (2007) Poverty Oriented Irrigation Policy in Kenya: Empirical Results and Suggestions for Reform. Discussion Paper, Deutsches Institut für Entwicklungspolitik, Bonn.

[12] Salami, A., Kamara, A.B. and Brixiova, Z. (2010) Smallholder Agriculture in East Africa: Trends, Constraints and Opportunities. Working Papers Series No. 105, African Development Bank, Abidjan.

[13] Fanadzo, M. (2012) Revitalisation of Smallholder Irrigation Schemes for Poverty Alleviation and Household Food Security in South Africa: A Review. African Journal of Agricultural Research, 7, 1956-1969. https://doi.org/10.5897/AJARX11.051

[14] Machethe, C.L., Mollel, N.M., Ayisi, K., Mashatola, M.B., Anim, F.D.K. and Vanasche, F. (2004) Smallholder Irrigation and Agricultural Development in the Olifants River Basin of Limpopo Province: Management Transfer, Productivity, Profitability and Food Security Issues. University of the North, School of Agriculture and Environmental Sciences, Limpopo.

[15] GIBB Africa (2011) Consultancy Services for Feasibility Study, Detailed Design and Preparation of Tender Documents for Lower Kuja Irrigation Development Project: Detailed Designs. Unpublished Technical Report, GIBB Africa Limited, Nairobi.

[16] Kenya National Bureau of Statistics (2018) Economic Survey 2018. http://www.knbs.or.ke

[17] Dlamini, N.S., Rowshon, M.K., Makhanya, M. and Sithole, S. (2014) The CDAA Framework for Development of Sustainable Large-Scale Smallholder Irrigation Schemes in Swaziland. Agriculture and Agricultural Science Procedia, 2, 386-393. https://doi.org/10.1016/j.aaspro.2014.11.054

[18] Mutambara, S. and Munodawafa, A. (2014) Production Challenges and Sustainability of Smallholder Irrigation Schemes in Zimbabwe. Journal of Biology, Agriculture and Healthcare, 4, 87-96. https://www.iiste.org

[19] Oduor, I.O. (2018) Farmer Participation in Project Management Phases, Endogenous Factors and Stability of Smallholder Irrigation Schemes in Busia County, Kenya. Doctoral Dissertation, University of Nairobi, Nairobi.

[20] Fanadzo, M., Chiduza, C. and Mnkeni, P.N.S. (2010) Overview of Smallholder Irrigation Schemes in South Africa: Relationship between Farmer Crop Management Practices and Performance. African Journal of Agricultural Research, 5, 3514-3523.

[21] Kisaka, S.E., Adhiambo, O.C., Ndege, D.M. and Muio, A.K. (2015) The Effect of Financial Deepening on the Performance of Smallholder Farmers in Homa Bay County, Kenya. Research Journal of Finance \& Accounting, 6, 141-155. https://www.iiste.org

[22] Miruri, R.K. (2017) Determinants of Performance of Irrigation Projects: Case of Nthawa Irrigation Project of Mbeere North Sub-County, Embu County, Kenya. Master's Thesis. University of Nairobi, Nairobi.

[23] Ngenoh, E., Kirui, L.K., Mutai, B.K., Maina, M.C. and Koech, W. (2015) Economic Determinants of the Performance of Public Irrigation Schemes in Kenya. Journal of Development and Agricultural Economics, 7, 344-352. https://doi.org/10.5897/JDAE2015.0676

[24] Ashraf, N., Giné, X. and Karlan, D. (2009) Finding Missing Markets (and a Dis- 
turbing Epilogue): Evidence from an Export Crop Adoption and Marketing Intervention in Kenya. American Journal of Agricultural Economics, 91, 973-990. https://doi.org/10.1111/j.1467-8276.2009.01319.x

[25] Muma, M. (2016) Mapping of Studies on Employment Creation of Agriculture and Agro-Processing in Kenya: Final Report. Institute of Development Studies, University of Nairobi, Nairobi.

[26] Karina, F.Z. and Mwaniki, A.W. (2011) Irrigation Agriculture in Kenya: Impact of the Economic Stimulus Programme and Long-Term Prospects for Food Security in an Era of Climate Change. Heinrich Böll Stiftung East \& Hon of Africa, Nairobi.

[27] Omiti, J., Otieno, D., Nyanamba, T. and Mc Cullough, E. (2009) Factors Influencing the Intensity of Market Participation by Smallholder Farmers: A Case Study of Rural and Peri-Urban Areas of Kenya. Afjare, 3, 57-82.

[28] Nkari, I.M. and Kibera, F.N. (2016) The Influence of Farmer Characteristics on Performance of Commercial Farmers in Kiambu County, Kenya. European Journal of Business and Social Sciences, 5, 63-78.

https://profiles.uonbi.ac.ke/fkibera/files/isaac m. nkari. kibera f.n. 2016 the infl uence of farmer characteristics on performance of commercial farmers in $\mathrm{k}$

[29] Ornan, H., Khobe, D. and Ornan, B. (2017) Adoption of Agricultural Innovations by Rice Farmers in Yola-South Local Government, Adamawa State, Nigeria. Global Journal of Science Frontier Research, 10, 78-81.

[30] Sahin, I. (2004) Detailed Review of Rogers' Diffusion of Innovations Theory and Educational Technology-Related Studies Based on Rogers' Theory. The Turkish Online Journal of Educational Technology, 5, 14-23.

[31] Scott, S.D., Plotnikoff, R.C., Karunamuni, N., Bize, R. and Rodgers, W. (2008) Factors Influencing the Adoption of an Innovation: An Examination of the Uptake of the Canadian Heart Health Kit (HHK). Implementation Science, 3, 41. https://doi.org/10.1186/1748-5908-3-41

[32] Rindfleisch, A., Malter, A.J., Ganesan, S. and Moorman, C. (2008) Cross-Sectional Verses Longitudinal Survey Research. Journal of Marketing Research, 45, 1-23. https://doi.org/10.1509/jmkr.45.3.261

[33] McCombes, S. (2019) Correlational Research. https://www.scribbr.com/methodology/correlational-research

[34] Krejcie, R.V. and Morgan, D.W. (1970) Determining Sample Size for Research Activities. Educational and Psychological Measurement, 30, 607-610. https://doi.org/10.1177/001316447003000308

[35] Hilton, C.E. (2015) The Importance of Pretesting Questionnaires: A Field Research Example of Cognitive Pretesting the Exercise Referral Quality of Life Scale. International Journal of Social Research Methodology, 20, 21-34. https://doi.org/10.1080/13645579.2015.1091640

[36] Lancaster, G.A., Dodd, S. and Williamson, P.R. (2002) Design \& Analysis of Pilot Studies: Recommendations for Good Practice. Journal of Evaluation in Clinical Practice, 10, 307-312. https://doi.org/10.1111/j..2002.384.doc.x 